\title{
STRATEGI PENGEMBANGAN BUDIDAYA JAMUR TIRAM SEBAGAI KOMODITAS PERTANIAN DI PERKOTAAN
}

\author{
Ni Wayan Purnami Rusadi ${ }^{1^{*}}$ \\ ${ }^{1}$ Politeknik Nasional Denpasar \\ *Corresponding author. niwayanpurnamirusadi@gmail.com \\ To cite this article: \\ Rusadi, N. (2020). Strategi Pengembangan Budidaya Jamur Tiram sebagai Komoditas Pertanian di \\ Perkotaan. Jurnal Ilmiah Membangun Desa dan Pertanian, 5(4), 122 - 128. \\ doi:http://dx.doi.org/10.37149/jimdp.v5i4.12722
}

Received: July 02, 2020; Accepted: August 26, 2020; Published: August 31, 2020

\begin{abstract}
This study aims to determine the most effective priority strategy to be applied in developing oyster mushrooms as an Agricultural Commodity in Urban City (Case Study of Oyster Mushroom Farmers in Denpasar City). The location selection method in this study was purposive. Stages of the study include the identification of internal factors, namely strengths and weaknesses, and external factors, namely the opportunities and threats faced by oyster mushroom farmers in Denpasar. The input stage is carried out by creating an IFAS matrix and an EFAS matrix. The matching stage uses the SWOT matrix and the decision stage uses QSPM. The results showed an alternative strategy obtained, namely improving the quality of products ranging from seedlings ( $F 1$ ), baglog (growing media), and oyster mushrooms; Form partnerships with baglog makers so they can reach price agreements; Form partnerships between fellow mushroom farmers so they can work together in the distribution of crops; Form partnerships with the oyster mushroom processing industry so that farmers get stable selling prices; Government programs to increase the capacity of mushroom cultivation for the community in a sustainable manner; Organizing a production and marketing management training program; Conducting oyster mushroom cultivation workshops for the general public; Improving environmental sanitation for making baglog or mushroom cultivation; Conduct training on post-harvest handling and waste generated after cultivation. The priority strategy obtained in the development of oyster mushrooms in the city of Denpasar is to conduct training on handling post-harvest and postcultivation waste produced with a value of 11,590 .
\end{abstract}

Keywords : EFAS; IFAS; Oyster mushrooms; SWOT; urban agriculture.

\section{PENDAHULUAN}

Menurut Sutarja (2010) jamur tiram adalah salah satu jenis jamur kayu yang awalnya berasal dari Belanda kemudian menyebar ke Indonesia sejak tahun 1988. Jamur tiram merupakan jenis jamur yang paling banyak dibudidayakan di Indonesia yakni mencapai $25 \%$. Adapun faktor yang mendukung pesatnya perkembangan jamur tiram adalah ketersediaan bahan baku (baglog) yang diperlukan untuk budidaya ada sepanjang tahun, pengaruh kondisi cuaca dan iklim di Indonesia yang sangat mendukung pertumbuhan jamur tiram, termasuk jenis jamur kosmopolitan yaitu mampu hidup di dataran rendah dan dataran tinggi meskipun hasilnya berbeda, serta produktivitas jamur tiram yang relatif tinggi per satuan waktu dan luas.

Menurut Meitasari \& Mursidah (2011) per 100 gram jamur tiram mengandung beberapa nutrisi diantaranya besi $18,2 \mathrm{mg}$; fosfor $717 \mathrm{mg}$; protein 30,4\%; kalium $3.793 \mathrm{mg}$; kalori $367 \mathrm{kal}$; kalsium 314 mg; karbohidrat 56,6\%; lemak 2,2\%; thiamin 0,20 mg; riboflavin 4,9 mg; niacin 77,2 mg; natrium 837 mg. Menurut Dananjaya, Suparta \& Ap (2014) keberhasilan usahatani terdiri dari tujuh indikator yakni terbentuk dan berkembangnya system pertanian organik menuju green economic, terciptanya lapangan pekerjaan pertanian melalui pengembangan diversifikasi usaha tani, berkembangnya aspek kelembagaan dan sumber daya manusia, meningkatnya intensifikasi dan ekstensifikasi pada usaha tani, berkembangnya insentif usaha tani melalui peningkatan sektor produksi serta efisiensi usaha tani, berkembangnya usaha ekonomi di pedesaan, dan meningkatkan 
pendapatan dan upah petani. Menurut Purnama (2010) tingkat keberhasilan usaha tani dapat dilihat berdasarkan efisiensi proses produksi yang dapat dikelompokkan berdasarkan efisiensi secara teknis dan ekonomis.

Pesatnya laju pertumbuhan populasi di perkotaan akan menimbulkan beberapa masalah lingkungan, polusi dan ketersediaan pangan. Apabila kondisi pertumbuhan populasi penduduk lebih besar dibandingkan laju produksi bahan pangan, maka dikhawatirkan akan terjadi krisis pangan. Jumlah bahan pangan yang tidak cukup akan berdampak pada ketergantungan antara suatu kawasan/wilayah terhadap kawasan lain. Dari data BPS 2013, Kota Denpasar mengalami alih fungsi luas lahan sawah subak dari 3.165 ha di tahun 1999 menjadi 2.506 ha di tahun 2013. Alih fungsi lahan terjadi karena desakan kebutuhan lahan untuk penggunaan di sektor bukan pertanian, seperti untuk permukiman, industri, jalan, sekolah dan perkantoran. Desakan tersebut mengandung dimensi ekonomi yang kuat sehingga berdampak pada penyusutan lahan pertanian. Melihat kondisi yang terjadi di lapangan, pertimbangan untuk mengembangkan sistem pertanian perkotaan dengan keterbatasan lahan mulai banyak digarap untuk membentuk suatu kemandirian pangan. Jamur tiram sebagai salah satu komoditas pertanian bisa dikembangkan sebagai komoditas pertanian perkotaan mengingat sistem budidayanya dapat dilakukan di lahan yang terbatas dan tidak bergantung pada kualitas tanah perkotaan yang notabene sudah terkontaminasi. Saat ini di Kota Denpasar sendiri jumlah konsumen jamur tiram meningkat sebab semakin berkembangnya rumah makan vegetarian dan outlet pengolahan jamur sebagai cemilan. Dari data Dinas Pertanian Provinsi Bali tahun 2013, tercatat 8 petani jamur tiram di Kota Denpasar dari 59 petani jamur tiram yang ada di Bali. Menurut Rusadi, Susrusa \& Ap (2015) jumlah petani jamur di Kota Denpasar tercatat sebanyak 36 orang yang tersebar di 4 kecamatan. Namun berdasarkan penelitian ini jumlah petani jamur di Kota Denpasar menurun padahal permintaan tergolong tinggi dan komoditas jamur tiram sesuai dengan pertanian perkotaan karena tidak diperlukan lahan yang subur. Menurut Widowati, Rizal \& Purwantiningdyah (2015) jumlah produksi jamur tiram yang ada di Kalimantan Timur setiap tahunnya terus mengalami peningkatan dan ditunjukkan dengan semakin banyak masyarakat yang mengembangkan usaha jamur tiram. Akan tetapi yang menjadi kendala yakni terbatasnya teknologi pengolahan jamur tiram serta pemasaran hasil pertanian sehingga perlu diikuti teknologi pengolahan hasil guna dalam meningkatkan kualitas jamur, mengantisipasi kelebihan produksi, diversifikasi produk serta meningkatkan nilai tambah. Menurut Retnaningsih, Veteran \& Nusantara (2017) yang menjadi strategi prioritas dalam pengembangan jamur tiram Kelompok Tani Aneka Jamur Desa Gondangmanis, Kecamatan Karangpandan, Kab. Karanganyar adalah mempertahankan dan meningkatkan kualitas produk pada bibit (F1), media tanam (baglog) dan jamur tiram. Di setiap daerah tentu memiliki strategi pengembangan yang berbeda-beda, untuk itu dilakukan penelitian tentang strategi pengembangan budidaya jamur tiram sebagai komoditas pertanian perkotaan (studi kasus Petani jamur tiram di Kota Denpasar).

\section{MATERI DAN METODE}

Metode pemilihan lokasi penelitian ini secara purposive (sengaja) yaitu petani jamur tiram yang ada di Kota Denpasar. Penelitian dimulai dari bulan Maret sampai dengan Juni 2020. Metode penentuan informan kunci dipilih secara purposive (sengaja) yaitu petani jamur tiram di Kota Denpasar yang sudah melakukan budidaya minimal 1 tahun dengan jumlah baglog minimal 1.000 buah dan Petugas Penyuluh Lapangan (PPL) Kota Denpasar yang juga melakukan budidaya jamur tiram. Jumlah informan kunci terdapat 16 orang yang tersebar di 4 kecamatan yaitu Kecamatan Denpasar Utara, Denpasar Barat, Denpasar Selatan dan Denpasar Timur. Dalam penelitian ini menggunakan data primer dan data sekunder. Data primer diperoleh dari responden penelitian melalui wawancara dan FGD (Focus Group Discussion). Sedangkan data sekunder diperoleh dari literatur, Dinas Pertanian Tanaman Pangan Dan Hortikultura Kota Denpasar, Dinas Pertanian Tanaman Pangan Provinsi Bali, dan Badan Pusat Statistik (BPS). Teknik pengumpulan data dilakukan dengan observasi, kuisioner online, wawancara dan FGD (Focus Group Discussion) secara online serta pencatatan. Metode analisis data pada penelitian ini yaitu analisis deskriptif untuk menganalisis faktor internal dan faktor eksternal pada petani jamur di Kota Denpasar. Kemudian dilakukan identifikasi faktor dengan menggunakan matrik IFAS dan EFAS. Dalam menggambarkan analisis SWOT dengan strategi alternatif, digunakan matriks dengan 4 kemungkinan yaitu strategi kekuatan-peluang (S-O), strategi kelemahan-peluang (W-O), strategi kekuatan-ancaman (S-T), dan strategi kelemahan-ancaman (W-T). Sedangkan dalam menentukan strategi prioritas digunakan matrik QSPM. Nilai dari matrik QSPM dengan nilai total terbesar dipilih sebagai alternatif strategi karena dianggap paling baik. 


\section{HASIL DAN PEMBAHASAN}

Hasil dari analisis matriks IFAS diperoleh nilai kekuatan dan kelemahan petani jamur tiram di Kota Denpasar yang ditunjukkan pada tabel 1. Sedangkan analisis Matriks EFAS diperoleh nilai peluang dan ancaman yang ditunjukkan pada tabel 2. Dari analisis matriks IFAS, skor yang diperoleh dari indikator strength (kekuatan) sebesar 1.52 dengan parameter tertinggi yaitu teknik budidaya jamur tiram yang mudah ditiru dengan skor 0.34. Pada indikator weakness (kelemahan) skor yang diperoleh 0.98 dengan parameter tertinggi yaitu hasil panen fluktuatif dan sulit diprediksi dengan skor 0.28. Berdasarkan hasil analisis matriks EFAS skor yang diperoleh dari indikator opportunities (peluang) sebesar 1.56 dengan parameter tertinggi yaitu terdapat pembuat baglog jadi yang siap dibudidayakan dengan skor 0.50. Pada indikator threats (ancaman) skor yang diperoleh 0.89 dengan parameter tertinggi yaitu pengaruh suhu/kelembapan udara dari lingkungan masih sangat berpengaruh dengan skor 0.30 . Berdasarkan matriks SWOT adapun alternatif strategi yang diperoleh sebagai berikut :

a. Strategi SO (Strength-Opportunity) yaitu strategi yang menggabungkan kekuatan internal dengan memanfaatkan peluang eksternal yang dinyatakan sebagai berikut :

- Meningkatkan kualitas produk mulai dari bibit (F1), baglog (media tanam) dan jamur tiram. Kualitas yang dimaksud dalam hal mutu, waktu, dan biaya. Petani jamur menginginkan baglog sebagai media tanam jamur dengan mutu yang baik, pengiriman tepat waktu, dan harga yang lebih murah dan terjangkau (Maharani, Suryawardani \& Ustriyana, 2016)

- Mengadakan workshop budidaya jamur tiram untuk masyarakat umum. Melalui alternatif strategi ini diharapkan petani mampu membudidayakan dan melakukan pengolahan pasca panen ketika saat panen jamur tiram berlimpah, sehingga produk dapat terserap dan memberikan nilai tambah.

b. Strategi WO (Weakness-Opportunity) yaitu strategi dalam meminimalkan kelemahan internal dengan memanfaatkan peluang eksternal, yang dinyatakan sebagai berikut :

- Adanya program pemerintah dalam peningkatan kapasitas budidaya jamur untuk masyarakat secara berkelanjutan.

- Membentuk kemitraan antar sesama petani jamur sehingga mampu bekerjasama dalam pendistribusian hasil panen.

- Membentuk kemitraan dengan industri pengolahan jamur tiram agar pembudidaya mendapatkan kestabilan harga jual.

c. Strategi ST (Strength-Threat) yaitu strategi dalam mengoptimalkan kekuatan internal yang dimiliki untuk menghindari ancaman, yang dinyatakan sebagai berikut :

- Meningkatkan sanitasi lingkungan pembuatan baglog ataupun budidaya jamur

- Membentuk kemitraan dengan pembuat baglog jamur tiram sehingga dapat mencapai kesepakatan dengan petani tentang harga media tanam

d. Strategi WT (Weakness- Threat) yaitu strategi defensif dalam meminimalkan kelemahan internal serta menghindari ancaman eksternal, yang dinyatakan sebagai berikut :

- Mengadakan program pelatihan manajemen produksi dan pemasaran

- Mengadakan pelatihan tentang penanganan pasca panen dan limbah yang dihasilkan pasca budidaya

Dalam pengambilan keputusan, alat analisis yang digunakan adalah matriks perencanaan strategi kuantitatif (Quantitative Strategic Planning Matrix-QSPM) dengan menentukan daya tarik relatif dari berbagai strategi yang muncul berdasarkan pada faktor strategis internal dan eksternal. Sedangkan nilai AS (Attrativeness Score) berfungsi dalam menunjukkan daya tarik masing-masing strategi terhadap faktor kunci internal dan eksternal usaha. Nilai AS yang diperoleh dari kuisioner dengan pertimbangan bahwa informan kunci dianggap paling mengetahui dan mengerti akan segala sesuatu yang dibutuhkan oleh kelompok tani. Pada nilai TAS (Total Attrativeness Scores) didapatkan dari hasil perkalian antara nilai AS dari setiap faktor kunci strategis dengan bobot rata-rata. Kemudian dilanjutkan dengan perhitungan nilai STAS (Sum Total Attrativeness Scores) yaitu menjumlahkan seluruh nilai TAS dari pada faktor internal dan eksternal. 
Tabel 1. Analisis Matriks IFAS

\begin{tabular}{|c|c|c|c|c|}
\hline No & Uraian & Bobot & Rating & Skor \\
\hline \multicolumn{5}{|c|}{ Strenght (Kekuatan) } \\
\hline 1 & Teknik budidaya jamur tiram yang mudah ditiru & 0.10 & 3.44 & 0.34 \\
\hline 2 & Tidak memerlukan lahan yang luas & 0.09 & 3.13 & 0.28 \\
\hline 3 & Jarak pengiriman dekat dengan pasar/konsumen & 0.03 & 3.13 & 0.09 \\
\hline 4 & Dapat dijadikan sebagai usaha sampingan & 0.05 & 3.19 & 0.16 \\
\hline 5 & Dapat meningkatkan pendapatan rumah tangga & 0.04 & 3.00 & 0.12 \\
\hline 6 & $\begin{array}{l}\text { Baglog sisa budidaya bisa dimanfaatkan sebagai pupuk bagi } \\
\text { tanaman lain }\end{array}$ & 0.04 & 3.06 & 0.12 \\
\hline 7 & Memiliki kandungan gizi yang bermanfaat bagi kesehatan & 0.05 & 2.69 & 0.13 \\
\hline 8 & Kualitas jamur tergolong baik dengan daya simpan cukup lama & 0.04 & 2.81 & 0.11 \\
\hline 9 & Jamur tiram dapat dipanen setiap hari & 0.06 & 2.56 & 0.15 \\
\hline \multirow{2}{*}{\multicolumn{5}{|c|}{ Total }} \\
\hline & & & & \\
\hline 1 & $\begin{array}{l}\text { Kapasitas budidaya tergolong kecil dengan rata-rata } 1.000 \\
\text { baglog/petani }\end{array}$ & 0.12 & 2.00 & 0.24 \\
\hline 2 & Hasil panen fluktuatif dan sulit diprediksi & 0.14 & 2.00 & 0.28 \\
\hline 3 & \multirow{2}{*}{$\begin{array}{l}\text { Manajemen usaha yang diterapkan masih sederhana } \\
\text { Jumlah produksi rata-rata } 300 \mathrm{~s} / \mathrm{d} 400 \mathrm{gr} / \mathrm{baglog} \text { dalam satu } \\
\text { periode }\end{array}$} & 0.07 & 2.13 & 0.15 \\
\hline 4 & & 0.06 & 1.88 & 0.11 \\
\hline 5 & $\begin{array}{l}\text { Tempat budidaya masih tersebar di masing-masing rumah } \\
\text { tangga (belum terpusat) }\end{array}$ & 0.05 & 1.88 & 0.09 \\
\hline \multirow[t]{2}{*}{6} & Baglog rawan terserang hama penyakit/terkontaminasi & 0.06 & 1.75 & 0.11 \\
\hline & Total & 0.50 & 11.63 & 0.98 \\
\hline
\end{tabular}

Tabel 2. Analisis Matriks EFAS

\begin{tabular}{|c|c|c|c|c|}
\hline No & Uraian & Bobot & Rating & Skor \\
\hline & Opportunities (Peluang) & & & \\
\hline 1 & Terdapat pembuat baglog jadi yang siap dibudidayakan & 0.14 & 3.56 & 0.50 \\
\hline 2 & $\begin{array}{l}\text { Terdapat banyak rumah makan vegetarian, outlet jamur crispy } \\
\text { dan supermarket sayuran segar }\end{array}$ & 0.13 & 3.00 & 0.39 \\
\hline 3 & Wawasan masyarakat terhadap pangan sehat tergolong tinggi & 0.07 & 3.00 & 0.21 \\
\hline 4 & Anjuran pemerintah tentang ketahanan pangan rumah tangga & 0.05 & 3.06 & 0.15 \\
\hline 5 & $\begin{array}{l}\text { Minat masyarakat dalam memanfaatkan pekarangan/lahan } \\
\text { tidak produktif menjadi sektor pertanian perkotaan }\end{array}$ & 0.04 & 3.06 & 0.12 \\
\hline 6 & $\begin{array}{l}\text { Mampu dijadikan peluang kerja baru untuk sector pertanian } \\
\text { perkotaan }\end{array}$ & 0.04 & 2.69 & 0.11 \\
\hline \multirow[t]{3}{*}{7} & Olahan jamur tiram beraneka ragam & 0.03 & 2.75 & 0.08 \\
\hline & Total & 0.50 & 21.13 & 1.56 \\
\hline & Threats (Ancaman) & & & \\
\hline 1 & $\begin{array}{l}\text { Pengaruh suhu/kelembapan udara dari lingkungan masih } \\
\text { sangat berpengaruh }\end{array}$ & 0.16 & 1.88 & 0.30 \\
\hline 2 & $\begin{array}{l}\text { Kemasan baglog masih berupa plastik sekali pakai yang tidak } \\
\text { ramah lingkungan }\end{array}$ & 0.04 & 1.75 & 0.07 \\
\hline 3 & Munculnya banyak pesaing dari pembudidaya baru & 0.06 & 1.63 & 0.10 \\
\hline 4 & $\begin{array}{l}\text { Bahan baku baglog berupa serbuk gergaji semakin sulit } \\
\text { didapatkan di Kota Denpasar }\end{array}$ & 0.03 & 1.94 & 0.06 \\
\hline 5 & $\begin{array}{l}\text { Waktu panen tidak menentu sehingga bila panen bersamaan } \\
\text { maka harga akan anjlok }\end{array}$ & 0.15 & 1.63 & 0.24 \\
\hline 6 & $\begin{array}{l}\text { Lingkungan yang kurang dijaga kebersihannya pada pembuat } \\
\text { baglog/petani yang melakukan budidaya menyebabkan } \\
\text { produksi kurang maksimal }\end{array}$ & 0.06 & 2.13 & 0.13 \\
\hline & Total & 0.50 & 10.94 & 0.89 \\
\hline
\end{tabular}


Tabel 3. Penentuan Alternatif Strategi dengan Analisis SWOT

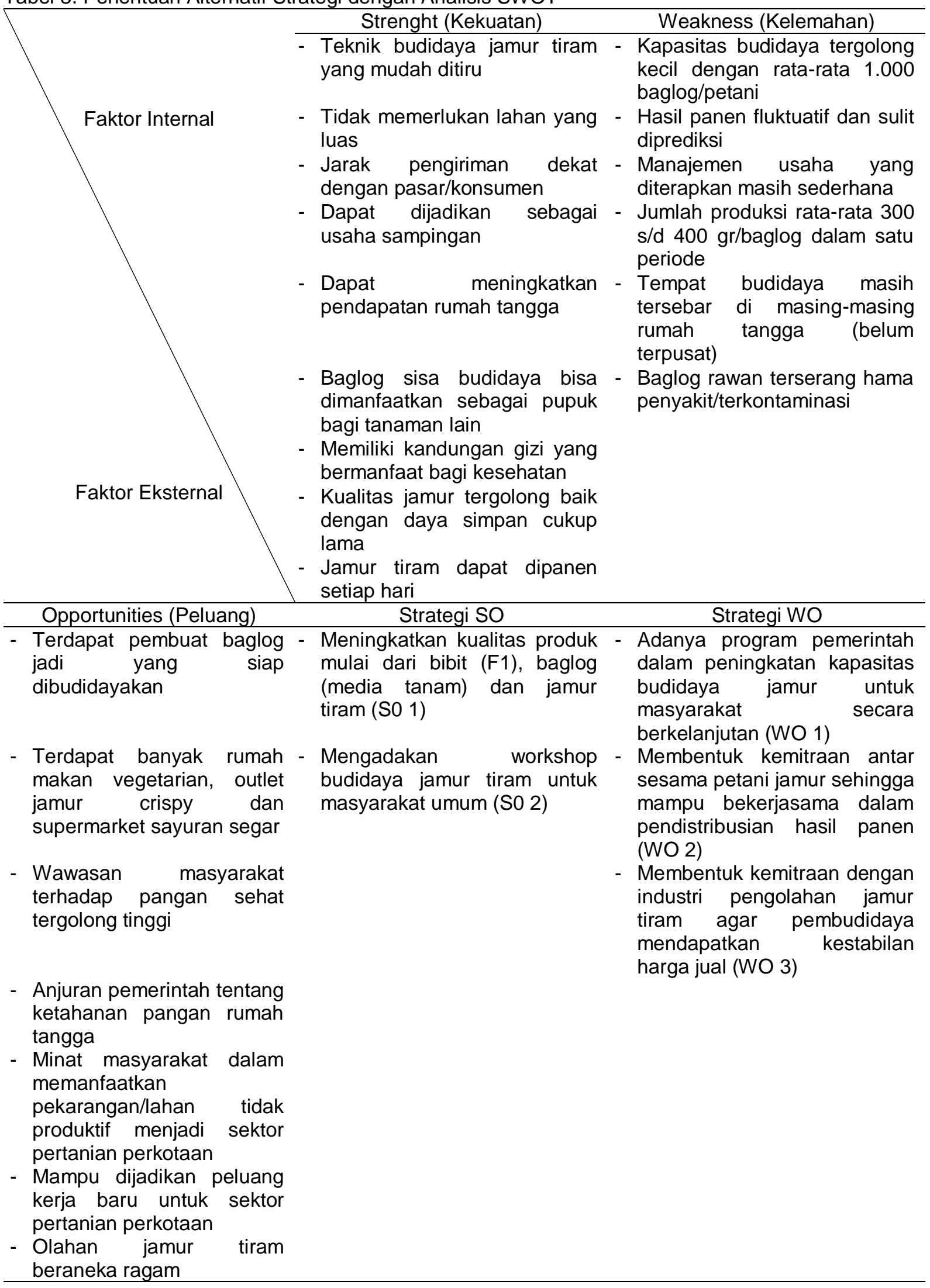


Threats (Ancaman)

- Pengaruh suhu/kelembapan udara dari lingkungan masih sangat berpengaruh

- Kemasan baglog masih berupa plastik sekali pakai yang tidak ramah lingkungan

- Munculnya banyak pesaing dari pembudidaya baru

- Bahan baku baglog berupa serbuk gergaji semakin sulit didapatkan di Kota Denpasar

- Waktu panen tidak menentu sehingga bila panen bersamaan maka harga akan anjlok

- Lingkungan yang kurang dijaga kebersihannya pada pembuat baglog/petani yang melakukan budidaya menyebabkan produksi kurang maksimal
Strategi ST

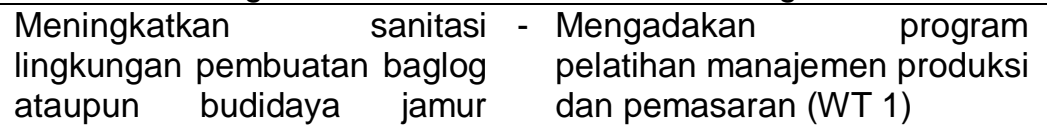
(ST 1)

Membentuk kemitraan dengan pembuat baglog sehingga mampu mencapai kesepakatan harga (ST 2)

\begin{abstract}
- Mengadakan pelatihan tentang penanganan pasca panen dan limbah yang dihasilkan pasca budidaya
\end{abstract} (WT 2)

Tabel 4. Hasil QSPM

\begin{tabular}{clc}
\hline No & \multicolumn{1}{c}{ Strategi } & Nilai TAS \\
\hline 1 & $\begin{array}{l}\text { Meningkatkan kualitas produk mulai dari bibit (F1), baglog (media tanam) dan } \\
\text { jamur tiram }\end{array}$ & 5.779 \\
2 & $\begin{array}{l}\text { Membentuk kemitraan dengan pembuat baglog jamur tiram sehingga dapat } \\
\text { mencapai kesepakatan dengan petani tentang harga media tanam }\end{array}$ & 5.086 \\
3 & $\begin{array}{l}\text { Membentuk kemitraan antar sesama petani jamur sehingga mampu } \\
\text { bekerjasama dalam pendistribusian hasil panen }\end{array}$ & 4.943 \\
4 & $\begin{array}{l}\text { Membentuk kemitraan dengan industri pengolahan jamur tiram agar } \\
\text { pembudidaya mendapatkan kestabilan harga jual }\end{array}$ & 5.153 \\
5 & $\begin{array}{l}\text { Adanya program pemerintah dalam peningkatan kapasitas budidaya jamur } \\
\text { untuk masyarakat secara berkelanjutan }\end{array}$ & 5.735 \\
7 & $\begin{array}{l}\text { Mengadakan program pelatihan manajemen produksi dan pemasaran } \\
\text { Mengadakan workshop budidaya jamur tiram untuk masyarakat umum }\end{array}$ & 4.315 \\
Meningkatkan sanitasi lingkungan pembuatan baglog ataupun budidaya & 5.454 \\
9 & $\begin{array}{l}\text { jemur } \\
\text { dihasilkan pasca budidaya }\end{array}$ & 4.979 \\
\hline
\end{tabular}

Menurut Widowati, Rizal \& Purwantiningdyah (2015) jumlah produksi jamur tiram yang ada di Kalimantan Timur terus mengalami peningkatan dan ditunjukkan dengan semakin banyaknya masyarakat yang mengembangkan usaha jamur tiram. Akan tetapi ada kendala yang dihadapi petani yaitu terbatasnya teknologi pada pengolahan jamur tiram serta pemasaran hasil pertanian saat panen melimpah sehingga perlu diikuti teknologi pengolahan pasca panen. Menurut Retnaningsih, Veteran \& Nusantara (2017) yang menjadi prioritas strategi dalam pengembangan jamur tiram di Kelompok Tani Aneka Jamur Desa Gondangmanis, Kecamatan Karangpandan, Kab. Karanganyar adalah dengan mempertahankan dan meningkatkan kualitas produk mulai dari bibit (F1), baglog (media tanam) dan jamur tiram. Di setiap daerah tentu memiliki strategi pengembangan yang berbeda-beda, untuk itu dilakukan penelitian tentang strategi pengembangan budidaya jamur tiram sebagai komoditas pertanian perkotaan (studi kasus Petani jamur tiram di Kota Denpasar). Hasil analisis dari QSPM dapat dilihat pada tabel 4. Analisis matriks QSPM yang diperoleh sebagai strategi prioritas yakni : Mengadakan pelatihan tentang penanganan pasca panen dan limbah yang dihasilkan pasca budidaya (STAS : 11.590), Meningkatkan kualitas produk mulai dari bibit (F1), baglog (media tanam) 
dan jamur tiram (STAS : 5.779), Adanya program pemerintah dalam peningkatan kapasitas budidaya jamur untuk masyarakat secara berkelanjutan (STAS : 5.735), Mengadakan workshop budidaya jamur tiram untuk masyarakat umum (STAS : 5.454), Membentuk kemitraan dengan industri pengolahan jamur tiram agar pembudidaya mendapatkan kestabilan harga jual (STAS : 5.153), Membentuk kemitraan dengan pembuat baglog jamur tiram sehingga dapat mencapai kesepakatan dengan petani tentang harga media tanam (STAS : 5.086), Meningkatkan sanitasi lingkungan pembuatan baglog ataupun budidaya jamur (STAS : 4.979), Membentuk kemitraan antar sesama petani jamur sehingga mampu bekerjasama dalam pendistribusian hasil panen (STAS : 4.943), dan Mengadakan program pelatihan manajemen produksi dan pemasaran (STAS : 4.315). Berdasarkan hasil penelitian terdahulu, dapat disimpulkan bahwa strategi prioritas pertama untuk diterapkan paa Petani jamur tiram di Kota Denpasar sesuai dengan Widowati, Rizal \& Purwantiningdyah (2015) di Kalimantan Timur sedangkan untuk strategi kedua sesuai dengan Retnaningsih, Veteran \& Nusantara (2017) di Kabupaten Karanganyar.

\section{KESIMPULAN}

Alternatif strategi yang diperoleh yaitu Mengadakan pelatihan tentang penanganan pasca panen dan limbah yang dihasilkan pasca budidaya (STAS : 11.590), Meningkatkan kualitas produk mulai dari bibit (F1), baglog (media tanam) dan jamur tiram (STAS : 5.779), Adanya program pemerintah dalam peningkatan kapasitas budidaya jamur untuk masyarakat secara berkelanjutan (STAS : 5.735), Mengadakan workshop budidaya jamur tiram untuk masyarakat umum (STAS : 5.454), Membentuk kemitraan dengan industri pengolahan jamur tiram agar pembudidaya mendapatkan kestabilan harga jual (STAS : 5.153), Membentuk kemitraan dengan pembuat baglog jamur tiram sehingga dapat mencapai kesepakatan dengan petani tentang harga media tanam (STAS : 5.086), Meningkatkan sanitasi lingkungan pembuatan baglog ataupun budidaya jamur (STAS : 4.979), Membentuk kemitraan antar sesama petani jamur sehingga mampu bekerjasama dalam pendistribusian hasil panen (STAS : 4.943), dan Mengadakan program pelatihan manajemen produksi dan pemasaran (STAS : 4.315). Strategi prioritas yang dapat dikembangkan untuk petani jamur tiram di Kota Denpasar yaitu mengadakan pelatihan tentang penanganan pasca panen dan limbah yang dihasilkan pasca budidaya (STAS : 11.590). Mengadakan pelatihan tentang penanganan pasca panen dan limbah yang dihasilkan pasca budidaya dapat dijadikan program terencana oleh Dinas Pertanian terkait. Kerjasama tersebut bisa dilakukan dengan kolaborasi antara masyarakat yang melakukan budidaya jamur, pengolahan pasca panen dan petani hortikultura dalam memanfaatkan limbah baglog sebagai pupuk untuk tanaman.

\section{REFERENSI}

Dananjaya, I., Suparta, N. \& Ap, I. G. S. (2014) Pengaruh Jiwa Kewirausahaan dan Manajemen Agribisnis terhadap Keberhasilan Gapoktan Simantri di Kabupaten Tabanan. Jurnal Manajemen Agribisnis, 2(2), pp. 131-142.

Maharani, N. M. K., Suryawardani, I. O. \& Ustriyana, I. N. G. (2016) Peningkatan Efisiensi Produksi Baglog Melalui Percepatan Waktu Siklus Produksi di Usaha Lancar Abadi Pendekatan Critical Path Method, E-Jurnal Agribisnis dan Agrowisata, 5(1).

Meitasari, Y. \& Mursidah (2011) Studi Tataniaga Jamur Tiram Putih (Pleurotus ostreatus) Di Kota Samarinda, EPP, 8(2), pp. 48-56.

Purnama, C. (2010) Motivasi dan Kemampuan Usaha dalam Meningkatkan Keberhasilan Usaha Industri Kecil (Studi Pada Industri Kecil Sepatu di Jawa Timur), Jurnal Manajemen dan Kewirausahaan, 12(2), pp. 177-184.

Retnaningsih, N., Veteran, U. \& Nusantara, B. (2017) Strategi Pengembangan Jamur Tiram (Pleurotus streatus) Di Kelompok Tani Aneka Jamur Desa Gondangmanis Kecamatan Karangpandan Kabupaten Karanganyar, 14(1), pp. 61-68.

Rusadi, N. W. P., Susrusa, K. B. \& Ap, I. G. S. (2015) Hubungan Antara Jiwa Kewirausahaan dan Manajemen Agribisnis terhadap Keberhasilan Usaha Jamur Tiram di Kota Denpasar. Jurnal Manajemen Agribisnis, 3(2), pp. 134-146.

Sutarja (2010) Produksi Jamur Tiram (Pleorotus ostreatus) Pada Media Campuran Serbuk Gergaji dengan Berbagai Komposisi Tepung Jagung dan Bekatul. Universitas Sebelas Maret.

Widowati, R., Rizal, M. \& Purwantiningdyah, D. N. (2015) Teknologi Pengolahan Hasil Jamur Tiram serta Analisis Usaha Taninya di Kota Balikpapan, Provinsi Kalimantan Timur, in Pros Sem Nas Masy Biodiv Indon, pp. 337-342. doi: 10.13057/psnmbi/m010228 